\title{
Arahan Pengembangan Desa Tertinggal Kabupaten Bondowoso Berdasarkan Aspek Sosial, Ekonomi, dan Infrastruktur
}

\author{
Amelia Puspasari dan Arwi Yudhi Koswara \\ Perencanaan Wilayah dan Kota, Fakultas Teknik Sipil dan Perencanaan, Institut Teknologi Sepuluh \\ Nopember (ITS) \\ Jl. Arief Rahman Hakim, Surabaya 60111 Indonesia \\ email: arwi_yudhi@urplan.its.ac.id
}

\begin{abstract}
Abstrak-Kabupaten Bondowoso merupakan salah satu kabupaten tertinggal di Provinsi Jawa Timur berdasarkan RPJMN tahun 2015-2019. Selain itu, terdapat kesenjangan antara nasional dan kabupaten sehingga perlu dilakukan identifikasi dan pengembangan desa tertinggal di Kabupaten Bondowoso. Permasalahan rendahnya kualitas dari Sumber Daya Manusia (SDM), pelayanan infrastruktur dasar yang belum memadai antara desa satu dengan desa lainnya, dan permasalahan tingginya angka kemiskinan yang terjadi di Kabupaten Bondowoso sehingga untuk mengatasi hal tersebut dilakukan arahan pengembangan desa tertinggal Kabupaten Bondowoso berdasarkan aspek sosial, ekonomi, dan infrastruktur. Penelitian ini bertujuan untuk merumuskan arahan pegembangan desa tertinggal di Kabupaten Bondowoso berdasarkan aspek sosial, ekonomi, dan infrastruktur. Penelitian ini menggunakan teori pegembangan wilayah, pengembangan daerah tertinggal, dan pembangunan perdesaan dengan menggunakan Analisis Faktor Eksplanatory untuk menentukan faktor yang berpengaruh terhadap ketertinggalan desa, Analisis Biplot digunakan untuk tipologi desa tertinggal berdasarkan aspek sosial, ekonomi, serta infrastruktur, dan Analisis Deskripsi digunakan untuk merumuskan arahan pengembangan desa tertinggal berdasarkan aspek-aspek yang diprioritaskan. Dari hasil penelitian terdapat empat faktor yang berpengaruh terhadap ketertinggalan desa di Kabupaten Bondowoso yaitu faktor kualitas SDM, perekonomian masyarakat, kondisi infrastruktur sosial, kondisi infrastruktur ekonomi. Berdasarkan hasil tipologi desa terdapat 95 desa tertinggal di Kabupaten Bondowoso yang terbagi menjadi 3 tipologi. Tipologi A sebanyak 9 desa, Tipologi B sebanyak 59 desa, dan Tipologi $\mathrm{C}$ sebanyak 27 desa. Arahan tipologi A peningkatan salah satu aspek SDM dan infrastruktur sosial atau perekonomian dan infrastruktur ekonomi. Arahan tipologi B peningkatan salah satu aspek SDM dan infrastruktur sosial dan atau perekonomian dan infrastruktur ekonomi. Arahan tipologi $\mathrm{C}$ peningkatan aspek SDM dan infrastruktur sosial serta perekonomian dan infrastruktur ekonomi. Arahan pengembangan desa tipe $\mathrm{C}$ dengan cara peningkatan SDM dengan cara meningkatkan angka partisipasi sekolah sampai tingkat SMP dengan sekolah satu atap, dan peningkatan perekonomian dengan memanfaatkan potensi desa.
\end{abstract}

Kata Kunci-Pengembangan desa, desa tertinggal, sosial, ekonomi, dan infratruktur

\section{PENDAHULUAN}

$\mathrm{P}$ ENGEMBANGAN desa tertinggal merupakan merupakan salah satu upaya dalam mengembangkan sebuah desa yang dihuni oleh masyarakat pedesaan dengan berbagai permasalahan sosial ekonomi dan keterbatasan fisik, menjadi desa maju dengan masyarakat pedesaan yang kualitas hidupnya sama atau tidak jauh tertinggal dibandingkan dengan masyarakat Indonesia lainnya. [1]

Kabupaten Bondowoso merupakan salah satu Kabupaten di Propinsi Jawa Timur yang termasuk kategori daerah tertinggal. Permasalahan ketertinggalan di Kabupaten Bondowoso adalah permasalahan pembangunan Sumber Daya Manusia (SDM), kemiskinan, dan permasalahan pemenuhan kebutuhan infrastruktur dasar yaitu infrastruktur sosial seperti sarana kesehatan dan pendidikan serta infrastruktur seperti prasarana jalan yang kurang memadai. [2]

Permasalahan SDM yang terdapat di Kabupaten Bondowoso adalah belum tercapainya sasaran utama pembangunan nasional yang terdapat pada RPJMN tahun 2015-2019 meliputi: (1) target rata-rata lama sekolah menurut RPJMN selama 8,25 tahun pada tahun 2014 sedangkan rata-rata lama sekolah penduduk Kabupaten Bondowoso selama 6,09 tahun atau setara dengan tamatan Sekolah Dasar; (2) target angka harapan hidup penduduk nasional (AHH) selama 72 tahun, sedangkan angka harapan hidup di Kabupaten Bondowoso hanya selama 63,79 tahun; dan (3) target angka melek huruf (AMH) penduduk nasional sebesar $95,82 \%$ sedangkan AMH Kabupaten Bondowoso belum mencapai target yaitu masih sebesar 78,95 $\%$. [3]

Permasalahan kemiskinan yang terdapat di Kabupaten Bondowoso adalah persentase penduduk miskin di Kabupaten Bondowoso sampai dengan tahun 2012 sebesar 16,75\% atau sekitar 123.600 jiwa penduduk Kabupaten Bondowoso masih tergolong penduduk miskin dengan garis kemiskinan sebesar Rp. 290.729,- dan Indeks Kedalaman Kemiskinan (IKK) sebesar 88,37. Persentase ini lebih besar daripada target pada RPJMN yaitu 8-10\% penduduk miskin, sedangkan di Kabupaten Bondowoso persentase penduduk miskin $>10 \%$. Sementara jika dilihat dalam cakupan yang lebih sempit, jumlah rumah tangga miskin sebesar 131.900 rumah tangga. [4]

Permasalahan lainnya di Kabupaten Bondowoso adalah rendahnya pelayanan infrastruktur wilayah baik dari segi kualitas maupun kuantitas masih merupakan persoalan besar di Kabupaten Bondowoso, yang harus segera diatasi karena dapat menghambat laju pembangunan daerah. Pada aspek transportasi, sarana dan prasarana merupakan persoalan yang perlu mendapat perhatian, dalam rangka memperpendek rentang kendali, untuk meningkatkan aksesibilitas dan mobilisasi manusia dan barang. Transportasi darat (jalan, 
jembatan, dan moda transportasi) masih sangat terbatas. Sepanjang $192.469 \mathrm{~km}$ prasarana jalan di Kabupaten Bondowoso kondisinya rusak parah dan sepanjang $78.453 \mathrm{~km}$ prasarana jalan kondisinya rusak ringan. Selain itu, kondisi sarana fasilitas kesehatan di Kabupaten Bondowoso hingga tahun 2013, ketersediaan Puskesmas di setiap Kecamatan masih belum memadai jika dibandingkan dengan jumlah penduduk yang harus dilayani, kecuali di Kecamatan Bondowoso. Rasio perbandingan antara Puskesmas dengan jumlah penduduk yang harus dilayanai di Kabupaten Kabupaten Bondowoso masih berada pada posisi 0,99 , rasio perbandingan Dokter dengan penduduk masih berada pada posisi 0,70, dan rasio perbandingan antara tenaga perawat dan bidan dengan jumlah penduduk masih berada pada posisi 0,83 . Rasio pelayanan ini akan terlayani jika nilai rasio lebih dari satu. [5]

Berdasarkan pemaparan masalah diatas untuk meminimalisir adanya desa yang tergolong tertinggal dan desa maju dibutuhkan arahan pengembangan desa tertinggal Kabupaten Bondowoso berdasarkan aspek sosial, ekonomi, dan infrastruktur. Arahan pengembangan ini nantinya digunakan untuk mengoptimalkan pengembangan wilayah pada desa di Kabupaten Bondowoso sehingga dapat terlepas dari kondisi ketertinggalan dan pertumbuhan serta perkembangan masingmasing desa di Kabupaten Bondowoso dapat dilakukan secara optimal. [6]

\section{METODE PENELITIAN}

\section{A. Jenis dan Pendekatan Penelitian}

Pendekatan yang digunakan dalam penelitian ini adalah pendekatan rasionalistik. [7] Jenis penelitian dalam penelitian ini adalah deskripti kuantitatif.

\section{B. Variabel Penelitian}

Variabel penelitian yang digunakan untuk mengidentifikasi faktor-faktor ketertinggalan desa di Kabupaten Bondowoso antara lain tingkat pendidikan, ratio ketergantungan pendudk, tenaga kerja, mata pencaharian penduduk, kemiskinan, tingkat kecukupan sarana pendidikan, tingkat kecukupan sarana kesehatan, kondisi perumahan, jarak antara pusat desa ke pusat kecamatan, tingkat ketersediaan sarana perdagangan, tingkat ketersediaan prasarana listrik, dan tingkat ketersediaan prasarana air bersih.

Variabel penelitian yang digunakanuntuk tipologi desa tertinggal di Kabupaten Bondowoso antara lain mata pencaharian penduduk, potensi desa, tingkat pendidikan, tingkat kecukupan sarana pendidikan, kondisi perumahan, tingkat ketersediaan sarana perdagangan, tingkat ketersediaan prasarana listrik, dan tingkat ketersediaan prasarana air bersih.

C. Mengidentifikasi Faktor-Faktor yang Berpengaruh Terhadap Ketertinggalan Desa di Kabupaten Bondowoso menggunakan Analisis Faktor Eksplanatori

Analisis Faktor Eksplanatori digunakan untuk mengidentifikasi faktor-faktor yang berpengaruh terhadap ketertinggalan desa di Kabupaten Bondowoso. Analisis Faktor Eksplanatori menggunakan bantuan SPSS 20.0 dengan tahapan-tahapan dalam analisis Faktor Eksplanatori adalah :

1) Pengelompokan variabel berdasarkan faktor yang sesuai dengan tinjauan pustaka.

2) Melakukan analisis setiap faktor dengan menggunakan bantuan oftware SPSS, jika variabel yang dianalisis memiliki nilai KMO (Kaiser Meyer Olkin Measure) > 0,5 maka faktor tersebut valid sedangkan jika nilai variabel yang dianalisis memiliki nilai KMO (Kaiser Meyer Olkin Measure) $<0,5$ maka faktor tersebut tidak valid.

D. Menganalisis Tipologi Desa Tertinggal Kabupaten Bondowoso Berdasarkan Aspek Sosial, Ekonomi, dan Infrastruktur menggunakan Analisis Biplot

Dalam analisis penentuan tipologi desa tertinggal pada penelitian ini menggunakan teknik analisis multivariate berjenis analisis biplot. Analisis Biplot menggunakan bantuan SPSS 20 dengan tahapan-tahapannya adalah :

1) Melakukan analisis komponen utama didasarkan pada variabel.

2) Melakukan analisis komponen utama kedua didasarkan pada obyek penelitian.

3) Setiap komponen utama dipilih 2 komponen yang pertama.

4) Membuat plot/variabel berdasarkan komponen utama pertama dan kedua

5) Membuat plot obyek-obyek berdasarkan komponen utama pertama dan kedua dengan menumpang tindihkan pada plot yang pertama.

E. Perumusan Arahan Pengembangan Desa Tertinggal Kabupaten Bondowoso Berdasarkan Aspek-Aspek yang diprioritaskan menggunakan Analisis Deskripti Narasi

Dalam penentuan arahan pengembangan desa tertinggal Kabupaten Bondowoso berdasarkan aspek-aspek yang diprioritakan menggunakan analisis deskriptif berbentuk narasi. Dalam melakukan metode analisis ini dilakukan dengan cara mengkomparasikan antara hasil analisis tipologi desa tertinggal dengan kondisi eksisting.

\section{HASIL DAN DISKUSI}

\section{A. Identifikasi Faktor yang Berpengaruh Terhadap Ketertinggalan Desa di Kabupaten Bondowoso}

Berdasarkan hasil tinjauan pustaka didapatkan faktor-aktor yang berpengaruh terhadap ketertinggalan adalah :

1) Aspek Sosial

Faktor kualitas sumber daya manusia terdiri-dari variabel tingkat pendidikan, rasio ketergantungan penduduk, dan jumlah tenaga kerja.

2) Aspek Ekonomi

Faktor kondisi perekonomian masyarakat terdiri dari variabel mata pencaharian penduduk bukan buruh tani, dan kemiskinan.

3) Aspek Infrastruktur

Faktor infrastruktur sosial terdiri-dari variabel tingkat kecukupan sarana pendidikan, tingkat kecukupan sarana kesehatan, jumlah tenaga kesehatan, dan kondisi perumahan. 
Faktor infrastruktur ekonomi terdiri-dari jarak dari pusat desa ke pusat kecamatan, kondisi jalan baik/buruk, tingkat ketersediaan sarana perdagangan, tingkat ketersediaan prasarana listrik, dan tingkat ketersediaan prasarana air bersih.

Berikut ini merupakan hasil perhitungan analisis Faktor Ekplanatori dengan menggunakan bantuan SPSS 20.0.

Tabel 1. Perhitungan KMO dan PCA

\begin{tabular}{|c|c|c|c|c|c|}
\hline Faktor & Variabel & $\begin{array}{l}\text { Nilai } \\
\text { KMO }\end{array}$ & $\begin{array}{c}\text { Nilai } \\
\text { PCA } \\
(1)\end{array}$ & $\begin{array}{c}\text { Nilai } \\
\text { PCA } \\
(2)\end{array}$ & Ket \\
\hline \multirow[t]{3}{*}{$\begin{array}{l}\text { Kualitas } \\
\text { SDM }\end{array}$} & $\begin{array}{l}\text { Tingkat } \\
\text { pendidikan }\end{array}$ & & 0,712 & - & Berpengaruh \\
\hline & $\begin{array}{l}\text { Ratio } \\
\text { ketergantungan } \\
\text { penduduk }\end{array}$ & 0,539 & - & 0.959 & $\begin{array}{l}\text { Tidak } \\
\text { Berpengaruh }\end{array}$ \\
\hline & $\begin{array}{l}\text { Jumlah tenaga } \\
\text { kerja }\end{array}$ & & - & 0,121 & $\begin{array}{l}\text { Tidak } \\
\text { Berpengaruh }\end{array}$ \\
\hline \multirow{3}{*}{$\begin{array}{l}\text { Kondisi } \\
\text { Perekono } \\
\text { mian } \\
\text { Masyara } \\
\text { kat }\end{array}$} & Mata & & - & 0,189 & Tidak \\
\hline & $\begin{array}{l}\text { pencaharian } \\
\text { penduduk } \\
\text { bukan buruh } \\
\text { tani }\end{array}$ & 0,500 & & & Berpengaruh \\
\hline & Kemiskinan & & 0,982 & - & Berpengaruh \\
\hline \multirow{4}{*}{$\begin{array}{l}\text { Kondisi } \\
\text { Infrastru } \\
\text { ktur } \\
\text { Sosial }\end{array}$} & Tingkat & & 0,778 & - & Berpengaruh \\
\hline & $\begin{array}{l}\text { kecukupan } \\
\text { sarana } \\
\text { pendidikan }\end{array}$ & & & & \\
\hline & $\begin{array}{l}\text { Tingkat } \\
\text { kecukupan } \\
\text { sarana } \\
\text { kesehatan }\end{array}$ & 0,614 & - & 0,833 & $\begin{array}{l}\text { Tidak } \\
\text { Berpengaruh }\end{array}$ \\
\hline & $\begin{array}{l}\text { Kondisi } \\
\text { perumahan }\end{array}$ & & 0,713 & - & Berpengaruh \\
\hline \multirow{3}{*}{$\begin{array}{l}\text { Kondisi } \\
\text { Infrastru } \\
\text { ktur } \\
\text { Ekonomi }\end{array}$} & $\begin{array}{l}\text { Jarak dari pusat } \\
\text { desa ke pusat } \\
\text { kecamatan }\end{array}$ & & - & 0,931 & $\begin{array}{l}\text { Tidak } \\
\text { Berpengaruh }\end{array}$ \\
\hline & $\begin{array}{l}\text { Tingkat } \\
\text { ketersediaan } \\
\text { sarana } \\
\text { perdagangan } \\
\text { Tingkat } \\
\text { ketersediaan } \\
\text { prasarana listrik }\end{array}$ & 0,727 & 0,870 & - & Berpengaruh \\
\hline & $\begin{array}{l}\text { Tingkat } \\
\text { ketersediaan } \\
\text { prasarana air } \\
\text { bersih }\end{array}$ & & 0,649 & - & Berpengaruh \\
\hline
\end{tabular}

Sumber : Penulis, 2016

Berdasarkan hasil tabel diatas, diketahui bahwa keempat faktor memenuhi syarat dalam analisis faktor. Faktor yang berpengaruh dalam ketertinggalan desa di Kabupaten Bondowoso yang terdiri dari 1) Faktor kualitas sumber daya manusia dengan variabel tingkat, (2) Faktor perekonomian masyarakat dengan variabel tingkat kemiskinan, (3) Faktor kondisi infrastruktur sosial dengan variabel tingkat kecukupan sarana pendidikan, dan kondisi perumahan serta (4) Faktor kondisi infrastruktur ekonomi dengan variabel tingkat kecukupan prasarana listrik, dan tingkat ketersediaan sarana perdagangan.

\section{B. Tipologi Desa Tertinggal Kabupaten Bondowoso} Berdasarkan Aspek Sosial, Ekonomi, dan Infratruktur

Dalam mengidentifikasi desa tertinggal Kabupaten
Bondowoso Berdasarkan Aspek Sosial, Ekonomi, dan Inrastruktur didapatkan 9 tipe tipologi dengan masing-masing karakteristik.

Tabel 2.

Tipologi Desa Tertinggal Kabupaten Bondowoso Berdasarkan Aspek Sosial, Ekonomi, dan Infrastruktur

\begin{tabular}{|c|c|c|c|}
\hline $\begin{array}{l}\quad \begin{array}{l}\text { Aspek } \\
\text { Sosial }\end{array} \\
\text { Aspek } \\
\text { Ekonomi }\end{array}$ & $\begin{array}{c}\text { Kuat dalam } \\
\text { Kualitas SDM } \\
\text { atau Kondisi } \\
\text { Infrastruktur } \\
\text { Sosial }\end{array}$ & $\begin{array}{c}\text { Lemah salah } \\
\text { satu aspek } \\
\text { Kualitas SDM, } \\
\text { dan atau } \\
\text { Kondisi } \\
\text { Infrastruktur } \\
\text { Sosial }\end{array}$ & $\begin{array}{l}\text { Lemah dua } \\
\text { aspek Kualitas } \\
\text { SDM, dan } \\
\text { Kondisi } \\
\text { Infrastruktur } \\
\text { Sosial }\end{array}$ \\
\hline $\begin{array}{l}\text { Kuat } \\
\text { Perekonomian, } \\
\text { atau Kondisi } \\
\text { Infrastruktur } \\
\text { Ekonomi }\end{array}$ & Tegalpasir & $\begin{array}{l}\text { Sucolor } \\
\text { Penanggungan }\end{array}$ & Sumberanom \\
\hline $\begin{array}{l}\text { Lemah salah } \\
\text { satu aspek } \\
\text { Perekonomian, } \\
\text { dan atau } \\
\text { Kondisi } \\
\text { Infrastruktur } \\
\text { Ekonomi }\end{array}$ & $\begin{array}{l}\text { Bandelan } \\
\text { Leprak } \\
\text { Ardisaeng } \\
\text { Sumberdumpyong }\end{array}$ & $\begin{array}{l}\text { Gadingsari } \\
\text { Baratan } \\
\text { Pelalangan } \\
\text { Pucang Anom } \\
\text { Grujugan Lor } \\
\text { Sumber Anyar } \\
\text { Jambeanom } \\
\text { Karanganyar } \\
\text { Besuk } \\
\text { Pandak } \\
\text { Wonoboyo } \\
\text { Sumbersari } \\
\text { Pakuniran } \\
\text { Kupang } \\
\text { Sukosari Kidul } \\
\text { Tegaljati } \\
\text { Mandiro } \\
\text { Kemuningan } \\
\text { Pakisan } \\
\text { Lombok Kulon } \\
\text { Tumpeng } \\
\text { Pasarejo } \\
\text { Kalianyar } \\
\text { Sumber Tengah }\end{array}$ & $\begin{array}{l}\text { Karang Sengon } \\
\text { Tanah Wulan } \\
\text { Gunungsari } \\
\text { Andungsari } \\
\text { Sukorejo } \\
\text { Sumber Wringin } \\
\text { Trembungan } \\
\text { Paguan } \\
\text { Kretek } \\
\text { Karang Melok } \\
\text { Mengen } \\
\text { Kemirian } \\
\text { Wonosuko } \\
\text { Kembang } \\
\text { Jebung Lor } \\
\text { Brambang } \\
\text { Darussalam } \\
\text { Lombok Wetan } \\
\text { Wonosari }\end{array}$ \\
\hline $\begin{array}{l}\text { Lemah dua } \\
\text { aspek } \\
\text { perekonomian, } \\
\text { dan Kondisi } \\
\text { Infrastruktur } \\
\text { Ekonomi }\end{array}$ & Karanganyar & $\begin{array}{l}\text { Sumberwaru } \\
\text { Solor } \\
\text { Ramban Wetan } \\
\text { Grujugan } \\
\text { Bajuran } \\
\text { Batusalang } \\
\text { Batu Ampar } \\
\text { Bercak Sari } \\
\text { Sumberjeruk } \\
\text { Blimbing } \\
\text { Sugerlor } \\
\text { Sekarputih } \\
\text { Tanggulangin } \\
\text { Klabang } \\
\text { Gunosari } \\
\text { Trotosari }\end{array}$ & $\begin{array}{l}\text { Kembangan } \\
\text { Pancoran } \\
\text { Sukowiryo } \\
\text { Kladi } \\
\text { Bercak } \\
\text { Suling Wetan } \\
\text { Jirek Mas } \\
\text { Jambesari } \\
\text { Pengarang } \\
\text { Pujerbaru } \\
\text { Maesan } \\
\text { Sumberpakem } \\
\text { Rejoagung } \\
\text { Sumberanyar } \\
\text { Gadingasari } \\
\text { Petung } \\
\text { Sumberkokop } \\
\text { Gentong } \\
\text { Sukosari } \\
\text { Purnama } \\
\text { Tlogosari } \\
\text { Sulek } \\
\text { Jumpong } \\
\text { Bendoarum } \\
\text { Kapuran } \\
\text { Traktakan }\end{array}$ \\
\hline
\end{tabular}

Sumber : Penulis, 2016 


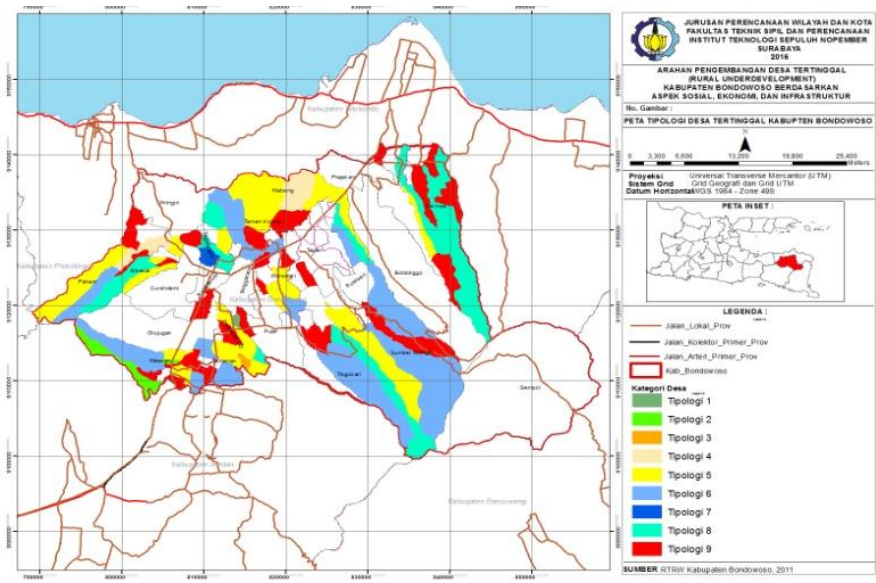

Gambar 1. Tipologi Desa Tertinggal Kabupaten Bondowoso Berdasarkan Aspek Sosial, Ekonomi, dan Infrastruktur

\section{Arahan Pengembangan Desa Tertinggal Berdasarkan Aspek-Aspek yang Diprioritaskan}

Arahan pengembangan desa tertinggal kabupaten Bondowoso menggunakan analisis deskriptif berbentuk narasi. Hasil narasi diambil dari sasaran kedua penelitian. Dari hasil penelitian didapatkan bahwa tipologi desa tertinggal Kabupaten Bondowoso berdasarkan aspek sosial, ekonomi, dan infrastruktur dibagi menjadi 3 tipologi, yaitu tipologi A yang terbagi 9 desa, tipologi B yang terdiri dari 59 desa, dan tipologi $\mathrm{C}$ yang terdiri dari 27 desa. Dari 95 desa yang diklasifikasikan sebagai desa tertinggal adalah desa pada tipe C. Arahan pengembangan desa tertinggal Kabupaten Bondowoso berdasarkan aspek sosial, ekonomi, dan infrastruktur diprioritaskan di tipologi $\mathrm{C}$ karena tipe $\mathrm{C}$ merupakan desa yang tertinggal terdiri dari 27 desa yang karakteristiknya lemah di aspek sosial, ekonomi, dan infrastruktur dengan arahan pengembangannya adalah peningkatan aspek sosial, ekonomi, dan infrastruktur.

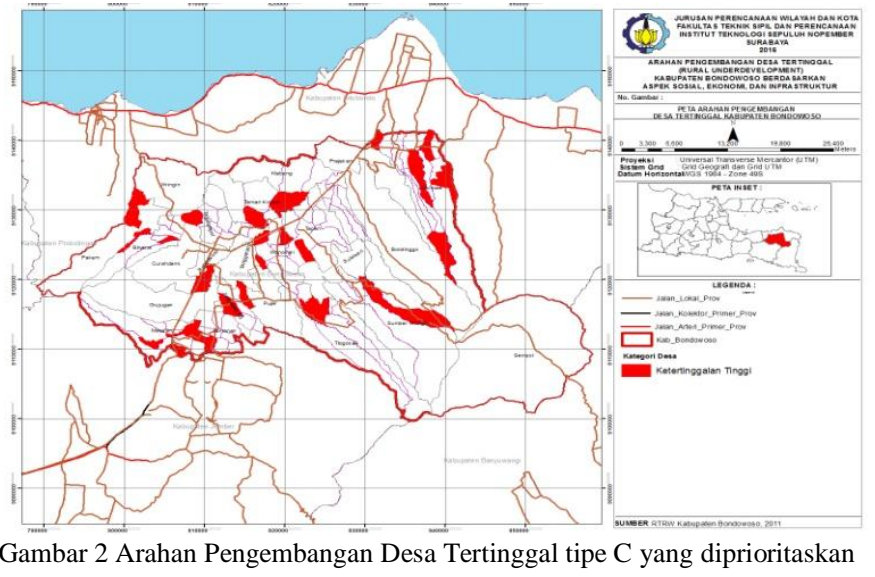

\section{KESIMPULAN}

Pada penelitian ini bertujuan untuk merumuskan arahan pengembangan desa tertinggal di Kabupaten Bondowoso berdasarkan aspek sosial, ekonomi, dan infrastruktur. Berikut ini merupakan hasil yang diperoleh dari penelitian ini :

1) Terdapat beberapa faktor yang berpengaruh dalam dalam ketertinggalan desa di Kabupaten Bondowoso yang terdiri dari 1) Faktor sosial yang terdiri dari tingkat pendidikan SD, dan tingkat pendidikan SMP, (2) Faktor ekonomi yang terdiri dari persentase keluarga miskin, (3) Faktor infrastruktur sosial yang terdiri dari variabel persentase SD, persentase SMP, serta persentase rumah permanen, dan (4) Faktor infrastruktur ekonomi yang terdiri dari variabel persentase pengguna PLN, persentase pengguna PDAM, persentase toko, dan persentase warung.

2) Terdapat 9 tipologi yang masing-masing terdiri dari tipologi 1 terdiri dari 1 desa, tipologi 2 terdiri dari 3 desa, tipologi 3 terdiri-dari 1 desa, tipologi 4 terdiri dari 4 desa, tipologi 5 terdiri dari 23 desa, tipologi 6 terdiri dari 18 desa, tipologi 7 terdiri dari 1 desa, tipologi 8 terdiri dari 16 desa, dan tipologi 9 terdiri dari 27 desa.

3) Dari 9 tipologi dari sasaran 2 disederhanakan menjadi 3 tipologi. Tipologi yang diprioritaskan adalah tipologi $\mathrm{C}$ yang lemah dari aspek sosial, ekonomi, dan infrastruktur sehingga arahan pengembangannnya adalah peningkatan aspek sosial, ekonomi, dan infrastruktur.

4) Arahan pada tipologi tipe $C$ diprioritaskan dengan cara peningkatan SDM dengan cara meningkatkan angka partisipasi sekolah sampai tingkat SMP dengan sekolah satu atap, dan peningkatan perekonomian dengan memanfaatkan potensi desa.

\section{DAFTAR PUSTAKA}

[1] Kementerian Desa Pembangunan Daerah Tertinggal dan Transmigrasi, KEMENDESA, 2015.

[2] Rencana Tata Ruang Kabupaten Bondowoso Tahun 2011-2031, Bondowoso: Pemkab Bondowoso, 2011.

[3] Badan Pusat Statistik Kabupaten Bondowoso., Bondowoso: BPS, 2013.

[4] R. Adisasmita, Pembangunan Perdesaan, Yogyakarta: Graha Ilmu, 2013.

[5] Sugiyono, Metode Penelitian Pendidikan (Pendekatan Kuantitatif, Kualitatis, R\&D), Bandung: Alfabeta, 2006.

[6] L. M. Watchen, Teknik-teknik statistika dalam Bisnis dan Ekonomi, Jakarta: Salemba Empat, 2014.

[7] A. Imam and S. , Sosiologi Kata dan Desa, Surabaya: Usaha Nasional Surabaya, 1993. 